\title{
3 Research Square \\ Validated ecofriendly LC-MS/MS and TLC- Densitometric Methods for Determination of Amlodipine besilate and Celecoxib in Presence of Toxic Impurity in pure and formulated tablets
}

Keywords:

Posted Date: February 3rd, 2021

DOI: https://doi.org/10.21203/rs.3.rs-154124/v2

License: (c) (1) This work is licensed under a Creative Commons Attribution 4.0 International License. Read Full License 


\section{Abstract}

The authors have requested that this preprint be removed from Research Square. 